\title{
Epidemiological, clinical, and laboratory aspects in a case series of canine hyperadrenocorticism: 115 cases (2010-2014) ${ }^{1}$
}

\author{
Francisco S.M. Martins ${ }^{2 *}$, Guilherme Luiz C. Carvalho², Luciana Jesus ${ }^{3}$, \\ Álan Gomes Pöppl ${ }^{2,4}$ (D) and Félix H.D. González ${ }^{2,5}$
}

\begin{abstract}
Martins F.S.M., Carvalho G.L.C., Jesus L., Pöppl A.G. \& González F.H.D. 2019. Epidemiological, clinical and laboratory aspects in a case series of canine hyperadrenocorticism: 115 cases (2010-2014). Pesquisa Veterinária Brasileira 39(11):900908. Hospital de Clínicas Veterinárias, Universidade Federal do Rio Grande do Sul, Av. Bento Gonçalves 9090, Agronomia, Porto Alegre, RS 90540-000, Brazil. E-mail: savio_mmartins@ hotmail.com

Diseases' clinical-epidemiological characterization assists in directing the diagnosis. The objective of this study was to describe epidemiological, clinical and laboratorial aspects of a case series of canine hyperadrenocorticism (HAC). One-hundred fifteen records of dogs diagnosed by the low dose dexamethasone suppression test and/or ACTH stimulation test were evaluated. Of the cases, $81.3 \%$ were HAC ACTH-dependent and 18.7\% HAC ACTH-independent. Females were more affected, representing $69.3 \%$ of the cases. The mean age was $10.3 \pm 2.5$ years and $64.9 \%$ were gonadectomized. Most of the patients were small size dogs, weighting less than $10 \mathrm{~kg}(73.9 \%)$. The most frequent breeds were: Poodle (27\%), Dachshund (17.4\%), and Yorkshire Terrier (10.4\%). The most frequent clinical manifestations were polyphagia (86\%), polydipsia $(82.6 \%)$, polyuria $(80 \%)$, abdominal enlargement $(82.6 \%)$, thin skin $(79.1 \%)$, muscular weakness $(78.3 \%)$ and panting $(74.8 \%)$. However, eventually unusual HAC-associated signs would be present in some dogs in a more important way compared with the classic disease's clinical signs. The CBC showed neutrophilia (66\%), eosinopenia (58.3\%) and lymphopenia (42.6\%) as main hematological abnormalities. The most common findings in serum biochemistry were increased alkaline phosphatase activity $(81.74 \%)$, increased ALT activity (62.6\%), hypercholesterolemia (66\%) and hypertriglyceridemia (54.7\%). Urinalysis revealed hyposthenuria in $14.9 \%$ and isostenuria in $13.5 \%$; besides proteinuria in $50 \%$ of the cases. Abdominal ultrasound showed bilateral adrenal hyperplasia (92.2\%) with adrenal asymmetry in $20.8 \%$ of the cases, in addition to hepatomegaly $(80.9 \%)$, biliary sludge $(67.8 \%)$ and hepatic hyperechogenicity (47.8\%). It was concluded that small size gonadectomized female dogs, mainly Poodles and Dachshunds, presented higher frequency in the population studied, and that the main changes observed in clinical and complementary tests were polyphagia, polyuria, polydipsia, abdominal enlargement, adrenal hyperplasia, increased phosphatase alkaline and hyperlipidemia. These results corroborated to a better disease characterization at Brazil. This work concluded that the population studied resembles the profile describe in European and North American epidemiologic studies, and that the HAC dog's clinical picture looks similar worldwide.
\end{abstract}

INDEX TERMS: Epidemiology, clinics, laboratory, case series, canine hyperadrenocorticism, dogs, Cushing syndrome, hypercortisolism, glucocorticoids.

\footnotetext{
${ }^{1}$ Received on June 14, 2019.

Accepted for publication on July 4, 2019.

${ }^{2}$ Graduate Program in Veterinary Science, Universidade Federal do Rio Grande do Sul (UFRGS), Av. Bento Gonçalves 9090, Agronomia, Porto Alegre, RS 91540-000, Brazil.*Corresponding author: savio_mmartins@hotmail.com

${ }^{3}$ Faculdade de Veterinária, Universidade Federal do Rio Grande do Sul (UFRGS), Av. Bento Gonçalves 9090, Agronomia, Porto Alegre, RS 91540-000.
}

\footnotetext{
${ }^{4}$ Departamento de Medicina Animal, Faculdade de Veterinária, Universidade Federal do Rio Grande do Sul (UFRGS), Av. Bento Gonçalves 9090, Agronomia, Porto Alegre, RS 91540-000.

${ }^{5}$ Departamento de Patologia Clínica Animal, Faculdade de Veterinária, Universidade Federal do Rio Grande do Sul (UFRGS), Av. Bento Gonçalves 9090, Agronomia, Porto Alegre, RS 91540-000.
} 
RESUMO.- [Aspectos epidemiológicos, clínicos e laboratoriais em uma série de cães com hiperadrenocorticismo: 115 casos (2010-2014).] A caracterização clínica-epidemiológica de doenças auxilia no direcionamento do diagnóstico. 0 objetivo deste trabalho foi descrever aspectos epidemiológicos, clínicos e laboratoriais de uma série de casos de hiperadrenocorticismo (HAC) canino. Foram avaliados 115 prontuários de cães diagnosticados pelo teste de supressão por baixa dose de dexametasona e/ou teste de estimulação com ACTH. Os casos de HAC ACTH-dependentes representaram 81,3\% da população, e 18,7\% foram ACTH-independentes. As fêmeas foram mais acometidas, representando $69,3 \%$ dos casos. A média de idade foi 10,3 $\pm 2,5$ anos e 64,9\% eram gonadectomizados. A maioria dos cães foi de porte pequeno, de até $10 \mathrm{~kg}(73,9 \%)$. As raças mais frequentes foram Poodle (27\%), Dachshund $(17,4 \%)$ e Yorkshire $(10,4 \%)$. As manifestações clínicas mais relatadas foram polifagia (86\%), polidipsia $(82,6 \%)$, poliúria (80\%), abdome pendular $(82,6 \%)$, atrofia cutânea $(79,1 \%)$, fraqueza muscular $(78,3 \%)$ e dispneia (74,8\%). Entretanto, eventualmente sinais clínicos pouco associados ao HAC se manifestaram de forma mais importante que os sinais clássicos da doença. 0 hemograma revelou neutrofilia (66\%), eosinopenia $(58,3 \%)$ e linfopenia $(42,6 \%)$ como principais alterações hematológicas. Na bioquímica sérica foi observado aumento de fosfatase alcalina $(81,74 \%$ dos casos), aumento da atividade da ALT (62,6\%), hipercolesterolemia (66\%) e hipertrigliceridemia $(54,7 \%)$. A urinálise revelou hipostenúria em 14,9\% e isostenúria em 13,5\%; além de proteinúria em $50 \%$ dos casos. A ecografia abdominal evidenciou hiperplasia bilateral de adrenal $(92,2 \%)$ com assimetria de adrenais em $20,8 \%$ dos casos, além de hepatomegalia (80,9\%), lama biliar $(67,8 \%)$ e hiperecogenicidade hepática $(47,8 \%)$. Concluiu-se que fêmeas castradas de pequeno porte, principalmente das raças Poodles e Dachshunds, apresentaram maior frequência na população estudada e que as principais alterações observadas clínicas e nos exames complementares foram polifagia, poliúria, polidipsia, aumento abdominal, hiperplasia da adrenal, aumento de fosfatase alcalina e hiperlipidemia. Estes resultados corroboram para melhor caracterização da doença no Brasil. Este estudo concluiu que a população estudada se assemelha ao perfil populacional de cães com HAC descrito em estudos Europeus e Norte Americanos de forma que o perfil dos casos ao redor do globo parece similar.

TERMOS DE INDEXAÇÃO: Epidemiologia, clínica, laboratório, série de casos, cães, hiperadrenocorticismo, síndrome de Cushing, hipercortisolismo, glicocorticoides.

\section{INTRODUCTION}

Cushing's syndrome or hyperadrenocorticism (HAC) is a multisystemic clinical condition caused by chronic higher exposure to glucocorticoids (Gilor \& Graves 2011). In dogs, hypercortisolism may occur secondarily to adrenocorticotropic hormone (ACTH) increased secretion by the hypophysis, classified as ACTH-dependent HAC. Less often, HAC may result from an increase in cortisol production by an adrenal gland neoplasm, known as ACTH-independent HAC (Peterson 2007, Behrend 2015).

HAC is considered the most prevalent dog's endocrine disease and a common disease in older dogs (Pöppl et al. 2016). Some breeds, such as Poodles and Dachshunds, present greater predisposition (Ling et al. 1979). Clinical manifestations begin, in most cases in a slow and progressive manner. Among such manifestations, polyuria, polydipsia, polyphagia and abdominal enlargement stand out. Regarding laboratorial aspects, stress leukogram, increase in alkaline phosphatase activity and hypertriglyceridemia are the main alterations (Behrend 2015).

Diagnosis is based on history and clinical evaluation, imaging exams and hormonal tests, such as the low-dose dexamethasone suppression test (LDDST) and the ACTH stimulation test (Behrend et al. 2013). Surgical and pharmacological approaches are among the therapeutic options. Therapeutic conduct is chosen based on HAC etiologic classification, since pituitary neoplasms are mostly treated with drugs whereas first-line treatment for adrenal gland neoplasms is adrenalectomy. Prognosis of canine HAC may vary according to case severity and the presence of comorbidities (Behrend 2015). There is a paucity of Brazilian data regarding HAC features. The aim of this study was to determine the frequency of clinical, laboratorial and ultrasonographic alterations in dogs with HAC, to foment recognition of suspicious cases in clinical routines and improve disease characterization at Brazil.

\section{MATERIALS AND METHODS}

Ethics Statement. This study was approved by the Research Ethics Committee from "Faculdade de Veterinária" of the "Universidade Federal do Rio Grande do Sul” (UFRGS) being also approved by the Ethics Committee on Animal Experimentation (CEUA) (Project 31755).

Study design. A retrospective study was conducted within a population with HAC diagnosis followed-up by an Endocrinology and Metabology Service from a Veterinary Teaching Hospital from 2010 to 2014. Clinical-epidemiological, laboratorial (CBC, serum biochemistry, and urinalysis), and ultrasonographic data of interest were obtained from standardized medical records.

Excluding criteria. Cases with diabetes mellitus, chronic kidney disease, and liver failure; or records that failed to contemplate information necessary for the study were not included. Also, dogs being treated with furosemide, glucocorticoids (iatrogenic HAC), and phenobarbital, were excluded from the study.

Hyperadrenocorticism classification. Etiological classification of HAC was characterized by the LDDST results profile and aspects of the abdominal ultrasonography, which classified HAC as either ACTH-dependent or ACTH-independent. Adrenal gland hyperplasia was considered in cases where the adrenal caudal pole thickness exceeded: $0.54 \mathrm{~cm}$ in dogs with up to $10 \mathrm{~kg}, 0.68 \mathrm{~cm}$ in dogs from 10 to $30 \mathrm{~kg}$, and $0.8 \mathrm{~cm}$ in dogs weighing over $30 \mathrm{~kg}$. Adrenal asymmetry was assumed as a difference between adrenal glands thickness greater than $0.4 \mathrm{~cm}$ (Soulsby et al. 2015).

Statistical analysis. Quantitative and qualitative variables were analyzed, and means, medians and variances were obtained; regarding qualitative data, distribution, counting and proportion were obtained.

\section{RESULTS}

A total of 115 HAC cases out 143 HAC cases attended from 2010 to 2014 were included based on exclusion criteria.

\section{Hyperadrenocorticism classification and population profile}

From those cases, $81.3 \%$ had ACTH-dependent HAC and $18.7 \%$ ACTH-independent HAC. Mean cortisol concentrations during the LDDST (basal, four and eight hours post-dexamethasone) were $6.2 \mu \mathrm{g} / \mathrm{dL}, 2.1 \mu \mathrm{g} / \mathrm{dL}$, and $4.7 \mu \mathrm{g} / \mathrm{dL}$ in the ACTH-dependent 
HAC group, while in the ACTH-independent HAC group the mean values were $5.3 \mu \mathrm{g} / \mathrm{dL}, 3.6 \mu \mathrm{g} / \mathrm{dL}$, and $4.1 \mu \mathrm{g} / \mathrm{dL}$. There was a greater disease occurrence in females, accounting for $69.3 \%$ of cases. In the population assessed, $65 \%$ of the dogs were gonadectomized. Mean age was $10.3 \pm 2.5$ years, ranging from four to 16 years. According to etiological classification, mean age of dogs with ACTH-dependent HAC was 9.3 years, and 11.4 years for dogs with ACTH-independent HAC. Fig. 1 shows the distribution of number of cases by age and etiological classification. Regarding size, 78\% were considered small dogs (up to $10 \mathrm{~kg}$ ), followed by $16 \%$ of medium size dogs (from 10 to $20 \mathrm{~kg}$ ), and large size dogs (over 20kg) corresponding to only $6 \%$ of cases. Table 1 shows breed distribution frequency.

\section{Laboratorial abnormalities}

The Figure 2 presents most frequent clinical manifestations in this case series. The mean CBC abnormalities were neutrophilia (66\%), eosinopenia (58.3\%), lymphopenia $(42.6 \%)$ and monocytosis (30,5\%). Mean values of red blood cells, hemoglobin and hematocrit were $6.4 \pm 1.0 \times 10^{6} / \mu \mathrm{L}$, $15.8 \pm 3.9 \mathrm{~g} / \mathrm{dL}$ and $46 \pm 7.2 \%$, respectively (Table 2 ). Normocytic normochromic anemia was present in $10.4 \%$ of the dogs with HAC, whereas $4.3 \%$ presented with macrocytic normochromic anemia. Among anemic dogs, 80\% were ACTH-dependent. Thrombocytosis (platelets $>500.000 / \mu \mathrm{L}$ ) was documented in $33.9 \%$ of the cases, with a mean platelets value of $479.900 / \mu \mathrm{L}$.

In $81.7 \%$ of the cases an increase in alkaline phosphatase activity was observed. Hypercholesterolemia was documented in $66 \%$ of the cases, while increase in ALT activity was present in $62.6 \%$, hypertriglyceridemia in $54.8 \%$, hyperglycemia in $30.5 \%$ and creatinine below $0.7 \mathrm{mg} / \mathrm{dL}$ in $48.7 \%$ of cases. Urinalysis has shown proteinuria in $48.7 \%$ of the cases and urinary density lower than 1.015 in $26.1 \%$. Table 2 shows mean values, standard deviation, minimum and maximum for each variable.

\section{Abdominal ultrasound}

The main alterations in the abdominal ultrasonography were bilateral adrenal gland hyperplasia (92.2\%) and hepatomegaly (80.9\%), followed by biliary sludge occurrence (67.8\%), hepatic hyperechogenicity (47.8\%) and renal parenchymal calcification (37.4\%). In $26.1 \%$ of cases, irregularity was found in the adrenal gland surface, with caudal pole asymmetry detected in

Table 1. Breed distribution of 115 dogs diagnosed with hyperadrenocorticism

\begin{tabular}{|c|c|c|}
\hline Breed & Number of cases & Percentage \\
\hline Poodle & 31 & 26.9 \\
\hline Dachshund & 20 & 17.3 \\
\hline Mongrel & 14 & 12.2 \\
\hline Yorkshire Terrier & 12 & 10.4 \\
\hline Bichon Frisé & 9 & 7.8 \\
\hline Maltese & 5 & 4.3 \\
\hline Shi-tzu & 4 & 3.4 \\
\hline Pinscher & 3 & 2.6 \\
\hline Schnauzer & 3 & 2.6 \\
\hline Cocker Spaniel & 2 & 1.7 \\
\hline West Highland White Terrier & 2 & 1.7 \\
\hline American Staffordshire Terrier & 1 & 0.9 \\
\hline Beagle & 1 & 0.9 \\
\hline Boxer & 1 & 0.9 \\
\hline French Bulldog & 1 & 0.9 \\
\hline Chihuaha & 1 & 0.9 \\
\hline Chow Chow & 1 & 0.9 \\
\hline Dogo Argentino & 1 & 0.9 \\
\hline Labrador & 1 & 0.9 \\
\hline Lhasa Apso & 1 & 0.9 \\
\hline Scotish Terrier & 1 & 0.9 \\
\hline
\end{tabular}

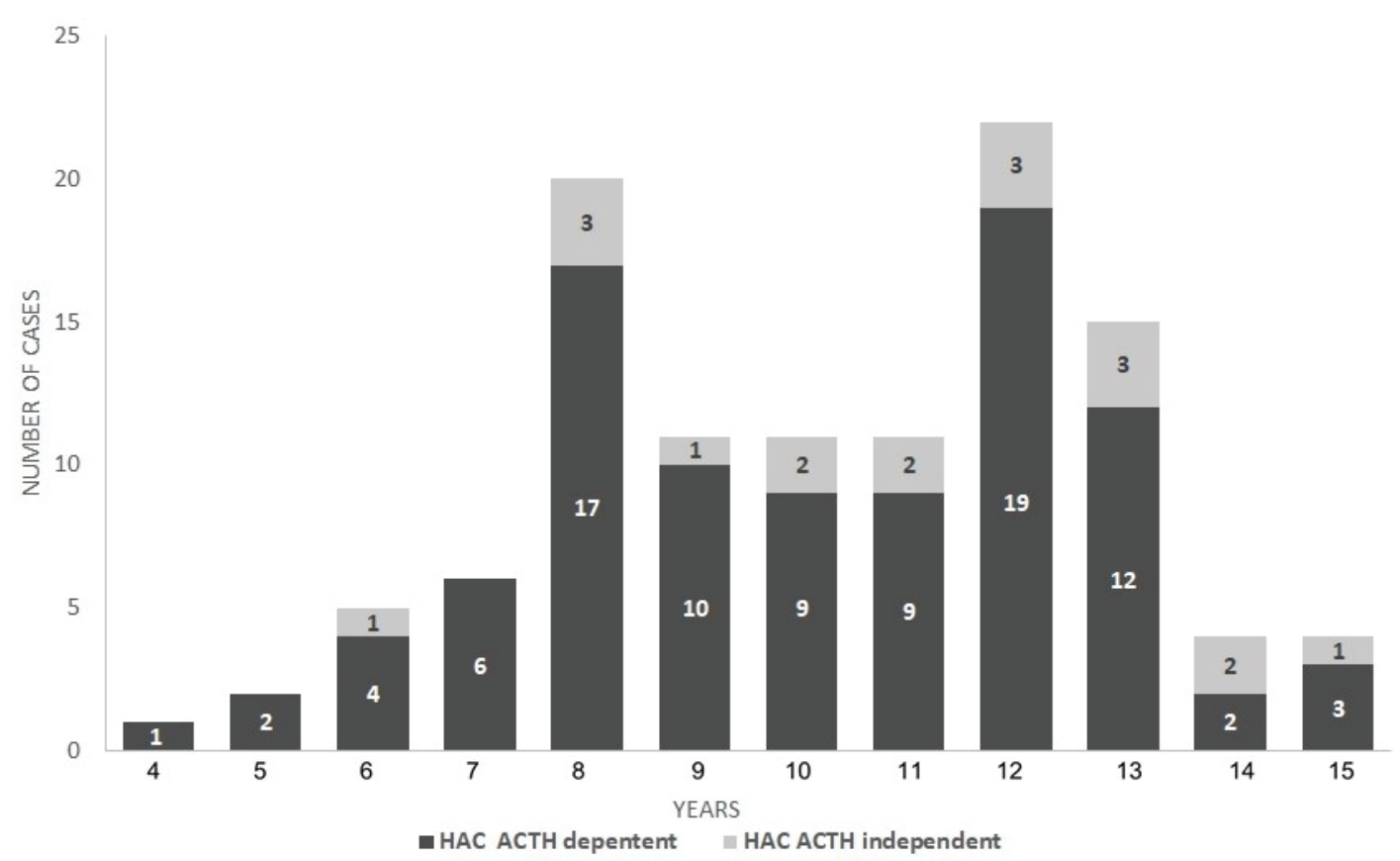

Fig.1. Dog's number distribution according to age and hyperadrenocorticism etiological classification. 


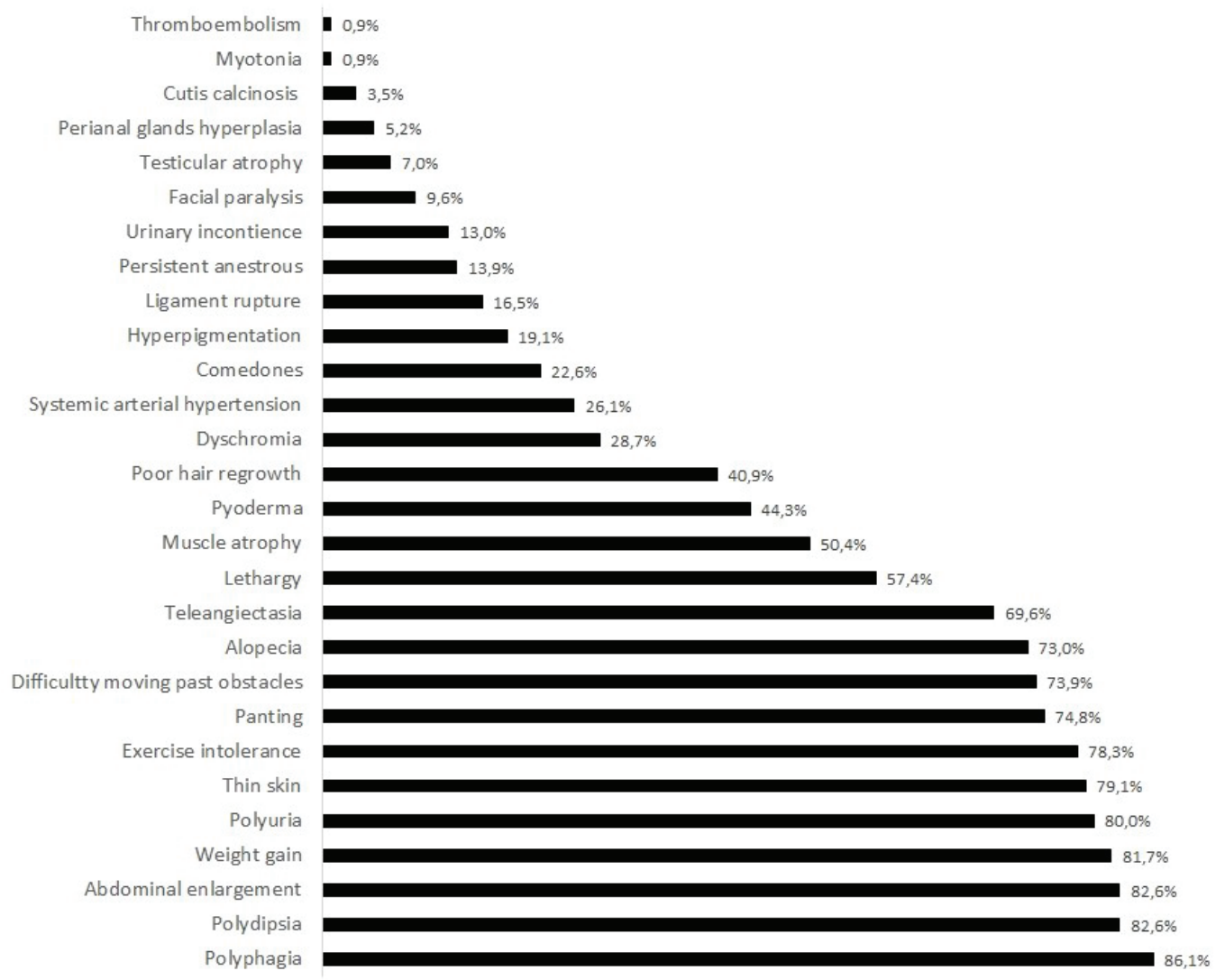

Fig.2. Clinical manifestation's percentage distribution in dogs diagnosed with hyperadrenocorticism.

Table 2. Mean values, standard deviation, range, and reference interval for the hematologic, serum biochemistry and urinary specific density in 115 dogs with hyperadrenocorticism

\begin{tabular}{lccc}
\hline \multicolumn{1}{c}{ Parameters } & $\begin{array}{c}\text { Mean } \\
\text { (standard deviation) }\end{array}$ & Range & $\begin{array}{c}\text { Reference } \\
\text { range }\end{array}$ \\
\hline Red blood cells & $6.4( \pm 1.06)$ & $3.5-8.28$ & $5.7-8.5 \times 10^{6} / \mu \mathrm{L}$ \\
Hemoglobin & $15.8( \pm 3.9)$ & $9.5-18.2$ & $12-18 \mathrm{~g} / \mathrm{dL}$ \\
Hematocrit & $46.0( \pm 7.1)$ & $29-63$ & $37-55 \%$ \\
Platelets & $479.9( \pm 174.5)$ & $342-1,000$ & $200-500 \times 10^{3} / \mathrm{mm}^{3}$ \\
Alkaline phosphatase & $391( \pm 1,102)$ & $33-6,516$ & $<156 \mathrm{U} / \mathrm{L}$ \\
ALT & $194.9 \pm \pm 177.9)$ & $7.2-923$ & $<102 \mathrm{U} / \mathrm{L}$ \\
Cholesterol & $330.8( \pm 143.2)$ & $100-1,013$ & $135-270 \mathrm{mg} / \mathrm{dL}$ \\
Triglycerides & $110.04( \pm 398)$ & $23-2,956$ & $32-138 \mathrm{mg} / \mathrm{dL}$ \\
Creatinine & $0.77 \pm 0.28)$ & $0.3-1.87$ & $0.5-1.5 \mathrm{mg} / \mathrm{dL}$ \\
Urea & $40( \pm 28.6)$ & $10-171$ & $21-60 \mathrm{mg} / \mathrm{dL}$ \\
Glucose & $105.3 \pm \pm 23.2)$ & $59-163$ & $65-118 \mathrm{mg} / \mathrm{dL}$ \\
Urinary density & $1.021 \pm \pm 0.011)$ & $1.006-1.052$ & $1.015-1.045$
\end{tabular}

$20.8 \%$ of cases, and parenchymal hyperechogenicity in $18.3 \%$. Among adrenal gland alterations, in the ACTH-dependent HAC group, heterogeneous parenchyma was observed in $11.1 \%$ and irregular surface in $17.2 \%$. In the ACTH-independent HAC group of dogs, asymmetry and heterogeneous parenchyma happened in $55 \%$ of the cases, and irregular shape in $60 \%$.

Left adrenal gland caudal pole average measures in the ACTH-dependent HAC group were $0.9 \pm 0.4 \mathrm{~cm}$ (range $0.4-3.3 \mathrm{~cm}$ ), while in right adrenal gland were $0.83 \pm 0.33 \mathrm{~cm}$ (range $0.35-2.6 \mathrm{~cm}$ ). In the ACTH-independent
HAC group, average of left adrenal glands was $1.31 \pm 0.76 \mathrm{~cm}$ (range $0.69-3.65 \mathrm{~cm}$ ) and $1.46 \pm 1 \mathrm{~cm}$ (range $0.5-4.5 \mathrm{~cm}$ ) for right adrenal glands. In small size dogs, average measures of adrenal glands caudal pole were $0.88 \pm 0.44 \mathrm{~cm}$ for the left adrenal gland and $0.86 \pm 0.44 \mathrm{~cm}$ for the right one. In medium size dogs, average measures of caudal pole were $1.17 \pm 0.6 \mathrm{~cm}$ for the left adrenal gland and $1.12 \pm 0.78 \mathrm{~cm}$ for the right one, whereas in large size dogs' average thickness of caudal pole of the left adrenal gland was $1.26 \pm 0.56 \mathrm{~cm}$ and $1.43 \pm 0.48 \mathrm{~cm}$ in the right one (Fig.3). 


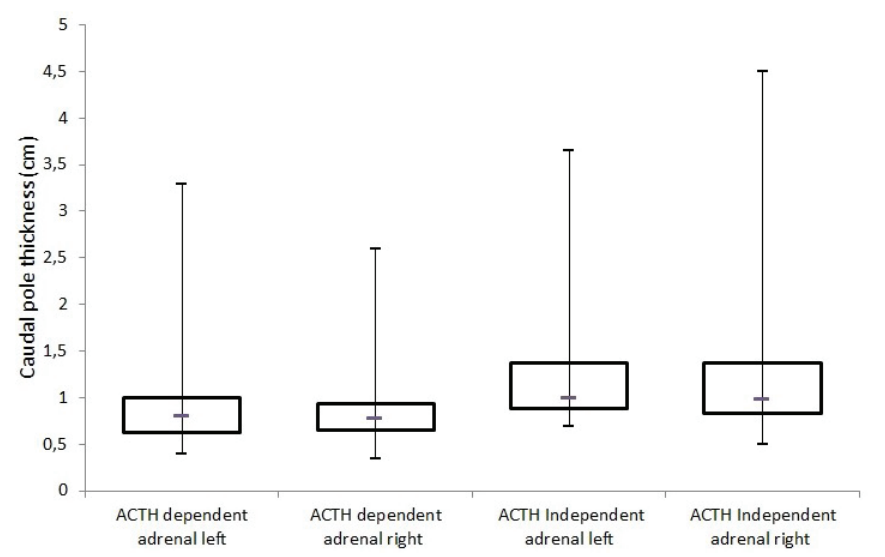

Fig.3. Left and right adrenal caudal pole thickness box plots of 115 dogs with hyperadrenocorticism according to etiological classification.

\section{DISCUSSION}

Characterization of the clinical-epidemiological profile collaborates to direct diagnosis process. Therefore, it is considered important to determine clinical, epidemiological and laboratorial aspects of diseases, especially ones that present a complex diagnostic, such as canine HAC. In the present study, classic disease's presentations were observed, with well-characterized clinical findings; however, in some patients, clinical manifestations were more discreet. Those cases did not present alterations considered frequent such as polyuria, polyphagia, increase in alkaline phosphatase activity, and hyperplasia of adrenal glands. Despite all the improvement in techniques and methodologies concerning hormonal analysis, evaluation of clinical aspects and complementary exams composition are essential to determine diagnosis (Benchekroun et al. 2010, Behrend 2015).

ACTH-dependent HAC was identified as being more frequent, accounting for about $80 \%$ of the cases, which is a similar result to what can be found in other studies (Reusch \& Feldman 1991, Theon \& Feldman 1998). Determination of the etiological classification of HAC is important not only to establish therapeutic protocol and prognosis (Fracassi et al. 2014, Behrend 2015), but also as a basis for the development of studies on pathogenesis, identifying factors that influence on incidence and etiology of this endocrinopathy. In this aspect, it seems reasonably that Brazilian canine HAC's population behaves in an analogous way that the patients worldwide.

Among possible factors, increased exposure to endocrine disruptors ${ }^{1}$, such as food contaminants (Koestel et al. 2017), toys, or plastic utensils (Wooten \& Smith 2013). Such substances interfere with several physiological mechanisms, from the inhibition of hormone synthesis (such as happens with lindane reducing StAR protein expression, decreasing

1 Note: Endocrine disruptors are substances exogenous to the organism that may interfere with synthesis, secretion, transport, metabolism or elimination of different hormones (Sonnenschtein \& Soto 2010). Examples: polychlorinated biphenyls, dioxins (industrial solvents), bisphenol A (plastics), PBDEs (flame retardants), dichlorodiphenyltrichloroethane (pesticides), diethylstilbestrol (pharmaceutical products) and parabens (preservatives). steroidogenesis) to steroid receptors binding, altering the process of transduction, signaling, and modulating enzymatic pathways in the metabolism of sexual hormones (for example, analogues of dichlorodiphenyltrichloroethane) (Koestel et al. 2017, Wooten \& Smith 2013).

Recent studies have evaluated the binding capacity of these pesticides to the glucocorticoid receptor (GR), demonstrating antagonistic effects from hormonal activity (Zhang et al. 2016). Such results, associated with knowledge of the cumulative potential and the possible effect over negative feedback on the pituitary gland, must be considered regarding the pathophysiological aspects of the disease. It is believed that a mutation in the structure of GR might reduce glucocorticoid sensitivity, causing an ACTH higher compensatory secretion. This hypothesis would justify the greater frequency of ACTH-dependent HAC. However, new evidence discredits this possibility (van Wijk et al. 2014). Despite significant improvement in the biomolecular techniques applied to endocrinology; etiopathogenesis and triggering factors of the mutations involved in HAC occurrence remain uncertain (Teshima et al. 2009, Kool et al. 2013). Those data therefore stress the clinical epidemiological studies importance and characterization.

HAC mainly affects middle-aged to older dogs, with a mean age of 10 years (Gallelli et al. 2010, Behrend 2015, Pöppl et al. 2016). It was previously found that dogs with ACTH-independent HAC tend to be more senile when compared to those with the ACTH-dependent form of the disease (Reusch \& Feldman 1991), which was observed in the present study. According to Kennedy et al. (2012) this is likely to happen due to the accumulation of damage and detrimental mutations in DNA, leading to compromise of genetic information, and relating aging to senile diseases such as cancer and neurodegeneration.

Most research agreed that HAC happens more often in female dogs (Reusch \& Feldman 1991, Gallelli et al. 2010, Pöppl et al. 2016). Nonetheless, there was no consensus regarding the existence of gender predisposition along time. In the present evaluation, ACTH-dependent HAC was more frequent in bitches, whereas ACTH-independent HAC was more frequent in male dogs. A study conducted in the seventies did not identify significantly differences in the sexual distribution between the groups assessed (Ling et al. 1979). In early nineties, Reusch \& Feldman (1991) indicated females HAC percentage over $60 \%$. Behrend (2015) stated a female gender predisposition.

Regarding reproductive condition, studies do not point out to greater HAC diagnosis incidence in gonadectomized dogs (O'Neill et al. 2016). Nonetheless, Belanger et al. (2017) have observed gonadectomy in males and females was significantly associated with a greater risk to develop HAC. In the study, spayed females were more frequent in the ACTH-dependent HAC group, which corroborates Peterson (2007) when stating that due to the interaction between female sexual hormones and the hypothalamic pituitary axis, females present greater predisposition to develop HAC, being the ACTH-dependent form more common. In fact, a recent study on canine HAC environmental risk-factors found gonadectomy as the only risk-factor identified within females' patients. HAC bitches in this study had an odds ratio greater than ten to be gonadectomized against control bitches paired by age and breed (Bock \& Pöppl 2018). 
O'Neill et al. (2016) have also reported that large breed dogs present lower risk to develop ACTH-dependent HAC when compared to small breed dogs. This aspect may be due to the diversity among dog breeds, with significant size and muscle mass alteration resulting from selective pressure in the formation and maintenance of modern breeds. It is evident that medium and small sized dogs are more HAC affected, which could be explained by data from a study that compared gene expression among dog sizes, identifying variants regarding a lower expression of IRS-4, IGSF-1 and ACSL-4 in small and medium sized dogs (Plassais et al. 2017). Such substrates are important in pituitary development (Wang et al. 2017) and in steroidogenesis (Midzak \& Papadopoulos 2016), which may explain the correlation between the occurrence of HAC and size. However, the breeds most reported in our study are also popular in our region, and the fact that they were overrepresented in this population does not absolutely means that they are more prone to HAC. Nevertheless, the breeds reported here are also commonly described in other South America and worldwide studies (Gallelli et al. 2010, Nozawa et al., 2014, Fracassi et al., 2015, Pöppl et al. 2016, Caragelasco et al. 2017, Miceli et al., 2017, Bennaim et al. 2019). Moreover, mongrel dogs may be less represented due to eventual owner's economic or even social conditions.

Knowing that the cases studied severity was variable and there is no correlation between gravity and cortisol concentration (Behrend 2015), it is interesting to point out the role of the $11 \beta$-hydroxysteroid dehydrogenase type 1 enzyme. Morgan et al. (2014) have shown glucocorticoids activation by $11 \beta$-HSD 1 in the peripheral tissues is a determining factor for the characterization of Cushing syndrome in mice. Data demonstrate that, even in high concentrations of glucocorticoids, in the absence of $11 \beta$-HSD1, mice are protected from clinical manifestations such as glucose intolerance, hyperinsulinemia, hepatic steatosis, adiposity, hypertension, myopathy and thin skin. This happens since glucocorticoids availability and action is also dependent on tissue-specific intracellular metabolism (Morgan et al. 2009), as well as on the level of expression of the enzyme, possibly affecting and changing clinical condition.

The results of the present study have resembled the data proposed by Behrend et al. (2013) that have classified the main HAC clinical manifestations as: frequent, less frequent, and infrequent. However, with the greater knowledge development on this endocrinopathy, identification of more subtle clinical signs becomes obvious. Besides the more classic manifestations seen in the study, less frequent ones such as lethargy/apathy, hyperpigmentation, comedones, pyoderma and poor hair regrowth were often observed. In the same way, infrequent ones, such as thromboembolism, ligament ruptures, facial nerve paralysis, cutis calcinosis, testicular atrophy, myopathy and persistent anestrous. Persistent anestrous low documentation may have occurred due to most females being already gonadectomized at diagnosis. The observation of a considerable number of patients with facial nerve paralysis in this case series calls attention to the necessity of broader studies to understand the origin of this little-reported alteration associated with HAC.

Regarding laboratory exams, complete blood count showed anemia in $17 \%$ of the cases. Normocytic normochromic anemia was the most frequent one, mainly affecting patients with ACTH-dependent HAC. Chervier et al. (2012) believes 14\% of the anemia cases in dogs are associated with endocrinopathies, with $80 \%$ of them being considered mild anemia. Such data goes against the expectation of mild erythrocytosis due to the eventual role of adrenal androgens on erythropoiesis. In the present study, frequency of anemia was lower in ACTH-independent cases. Chervier et al. (2012) points out that cancer-related anemia happen more often than anemia from chronic inflammation. In some cases, anemia could be present as a result from an induced euthyroid sick syndrome, due to the suppressive action of chronic hypercortisolemia in the secretion of thyrotrophic hormone (TSH) and reduced thyroxine $\left(\mathrm{T}_{4}\right)$ deiodination to triiodothyronine $\left(\mathrm{T}_{3}\right)$ (Behrend 2015). It is important to note that anemia could be predictive of comorbidities and may help in patient's prognosis. Further investigation is warranted in those cases.

The most common findings in the leukogram were neutrophilia without left shift and eosinopenia. Behrend (2015) indicates that neutrophilia is due to neutrophils demargination from capillaries, monocytosis is secondary to a lower stimulus for circulation removal, lymphopenia is due to steroid-induced sequestration and cellular destruction, and eosinopenia results from bone marrow sequestration.

Thrombocytosis is considered a common finding in HAC. Studies indicate it may occur in $60 \%$ to $80 \%$ of dogs with HAC (Herrtage \& Ramsey 2012, Pace et al. 2013, Rose et al. 2013). In the present study it was observed in $33.9 \%$ of the cases assuming 200.000-500.000/ $\mathrm{mm}^{3}$ platelets as reference range. Until the present moment, the role and relevance of thrombocytosis in HAC dogs is not known (Behrend 2015), since an association between hypercoagulability and canine HAC has not yet been proved. There is, however, indication to evaluate the coagulation profile of these patients, through monitoring of coagulation factors and counting of platelets, as well as identifying and treating possible factors associated, such as hypertension, hypercholesterolemia, and diabetes mellitus (Rose et al. 2013, Klose et al. 2011).

Concerning alterations in biochemical exams, the most frequent one was an increase in serum alkaline phosphatase (ALP) activity, due to the glucocorticoid-induced isoenzyme. However, hepatic vacuolation due to glycogen overload, favoring intrahepatic cholestasis also collaborate to ALP increases (Kooistra \& Galac 2010). Higher ALP serum activity is one of the most common findings in HAC canine patients (Herrtage \& Ramsey 2012, Behrend 2015). In the present study, however; about $20 \%$ of the cases did not show this abnormality. Therefore, it is of interest to emphasize that patients with hypercortisolemia may present values for ALP activity within reference range, and one should not discard HAC from differential diagnosis list based on a normal ALP.

In most cases, ALT shows a discrete elevation, caused by an increase in hepatocellular membrane permeability due to glycogen deposition in hepatocytes, with eventual cellular death low level (Behrend et al. 2013). Hence, greater hepatic compromise must be considered in HAC cases with higher ALT values. In the present study, increase in serum ALT activity was observed in more than half of the dogs, which may justify the adjunct use of drugs that act controlling oxidative stress and inflammation during HAC treatment (AU et al. 2013).

Urea values were elevated in almost $30 \%$ of the cases, possibly indicating glucocorticoid-induced protein catabolism. Nonetheless, both urea and creatinine may be at lower end 
of reference range (creatinine $<0.7 \mathrm{mg} / \mathrm{dL}$ was observed in almost $50 \%$ of the cases in the study). This condition happens due to glucocorticoid-induced muscle catabolism along with polyuria, which promotes a greater urinary loss of nitrogen compounds, and an increased glomerular filtration rate caused by glucocorticoids (Behrend et al. 2013, Herrtage \& Ramsey 2012).

Hyperlipidemia was present in about $60 \%$ of the dogs with HAC. According to Ramsey \& Ristic (2007), hypercholesterolemia is observed in $90 \%$ of the dogs with HAC and many of these animals also present hypertriglyceridemia. It is likely that the condition happens due to chronic glucocorticoid-induced insulin resistance, with a lower lipoprotein lipase activation and greater hormone-sensitive lipase activation.

Miceli et al. (2017) have observed that dogs with fasting blood glucose levels above $105 \mathrm{mg} / \mathrm{dL}$, with dyslipidemia (triglycerides $>221.2 \mathrm{mg} / \mathrm{dL}$ and hypercholesterolemia $>350 \mathrm{mg} / \mathrm{dL}$ ), and cortisol:creatinine ratio $>100 \times 10^{-6}$, present greater risk of diabetes mellitus developing. The study highlights that $93.7 \%$ of the dogs with HAC and DM presented ACTH-dependent HAC, indicating a higher predisposition of this group to develop diabetes mellitus, and even suggests preventive insulin therapy. Other study has also shown an association between HAC and diabetes mellitus in 16\% of cases (Pöppl et al. 2016). Biomolecular data has indicated a reduction in the expression of genes involved in insulin signaling mechanisms (IRS-1, IRS-2, PI3-Ke Akt-2) of dogs with HAC, thus contributing to insulin resistance induction (Nozawa et al. 2014).

Urinalysis showed proteinuria in almost $50 \%$ of cases and hyposthenuria (urinary density $<1,008$ ) in $15 \%$ of them. These alterations are reported as being the main urinary findings in dogs with HAC (Behrend et al. 2013). It is important to note that even after treatment and decrease in glomerular filtration rate; proteinuria persists in some dogs (Smets et al. 2012a). The reason for this is related to glucocorticoid-induced dysfunction both at glomerular and tubular level in dogs with untreated HAC. This observation warrant monitoring of renal function and systemic hypertension control (Smets et al. 2012b). Moreover, other studies have shown that proteinuria is directly correlated with blood pressure (Vidal et al. 2018), and that HAC initial treatment with trilostane does not seem to be enough to normalize altered cardiovascular parameters in dogs (Soares et al. 2016). In this scenario, it is important to note that the overexpression of the $11 \beta$-hydroxysteroid desidrogenase-1 enzyme in visceral adipose tissue of HAC patients could play a role in the maintenance of hypercortisolism in dogs with HAC (Miceli et al. 2018).

In the abdominal ultrasounds, adrenal glands bilateral enlargement was observed in $92 \%$ of the cases. Benchekroun et al. (2010) state that the bilateral enlargement of the adrenals suggests that HAC is ACTH-dependent, whereas the unilateral enlargement of the gland points towards ACTH-independent HAC. Even though it was adrenal abnormalities in almost all the cases analyzed, studies indicate that the adrenal glands may present unusual sizes or alterations in any type of HAC (Benchekroun et al. 2010). Nevertheless, it was observed that the frequency of adrenal glands with irregular shape was of $60 \%$ in the group of dogs with ACTH-independent HAC, there is, 3.5-fold greater than in the ACTH-dependent HAC group. It is important to highlight that no alterations were found in the adrenal glands in $7 \%$ of the cases, which corroborates the concept that the possibility of HAC cannot be ruled out based on the identification of adrenal glands with normal size and aspect (Behrend et al. 2013). Pagani et al. (2017) have compared the alterations described in the ultrasonography against the histologic findings. Their results indicated bilateral lesions in the adrenals as predictive of benign lesions, such as cortical hyperplasia. On the other hand, large masses $(>20 \mathrm{~mm})$ and surface irregularities, were predictive of malignant neoplasm. Such structural characteristics could help diagnosis and investigation. Even though, they are not pathognomonic, especially since some ACTH-dependent cases develop macronodular hyperplasia of the adrenal glands and since adrenal hyperplasia because of the hypothalamic pituitary adrenal axis (HPA) activation is a common finding.

Also, a high frequency of hepatomegaly was verified in abdominal ultrasounds, with liver hyperechogenicity being observed in almost $50 \%$ of the cases. This finding is compatible with a steatosis condition due to steroids-induced hepatic glycogen overload (Ramsey \& Ristic 2007). Biliary sludge was observed in almost $70 \%$ of the cases, attesting to the high occurrence of cholestatic complications in dogs with HAC. It is believed that cholestatic disorders physiopathology in patients with ACTH-dependent HAC may be related to the cholesterol metabolism. Kim et al. (2017) have observed an association between ACTH-dependent HAC and cholestatic disease, and that patients with such comorbidity need higher doses of trilostane. A recent study has also shown it is possible that gallbladder mucoceles and biliary sludge have the same physiopathology, thus representing a continuous disease, with biliary sludge being considered the stage before gallbladder mucoceles appearance (Kutsunai et al. 2014, Mizutani et al. 2017).

\section{CONCLUSIONS}

This work concluded that the population studied resembles the profile describe in European and North American epidemiologic studies, and that the HAC dog's clinical picture looks similar worldwide. This clinicopathological characterization of a South Brazilian cohort contributes for a better recognition of this important, challenging, and frequent disease at Brazil.

Special attention should be present in front of vague clinical signs or minor laboratory and ultrasound abnormalities compatible with HAC. Due to the greater dog's life expectancy, and better early HAC recognition, to know how local HAC cases behave in contrast with international literature helps to support accurate diagnosis in clinic routine. Moreover, eventually unusual HAC-associated signs would be present in some dogs in a more important way compared with the classic disease's clinical signs. To recognize the large spectrum of clinicopathological abnormalities secondary to this interestingly endocrine disease is a key factor to improve HAC suspicion and investigation.

Conflict of interest statement.- The authors declare no conflict of interest.

\section{REFERENCES}

Au A.Y., Hasenwinkel J.M. \& Frondoza C.G. 2013. Hepatoprotective effects of S-adenosylmethionine and silybin on canine hepatocytes in vitro. J. Anim. Physiol. Anim. Nutr. 97(2):331-341. <http://dx.doi. org/10.1111/j.1439-0396.2012.01275.x> <PMid:22320165> 
Behrend E.N. 2015. Canine hyperadrenocorticism, p.377-444. In: Feldman E.C., Nelson R.W., Reusch C.E., Scott-Moncrieff J. \& Behrend E.N. (Eds), Canine and Feline Endocrinology. 4th ed. W.B. Saunders, St Louis. <http:// dx.doi.org/10.1016/B978-1-4557-4456-5.00010-9>

Behrend E.N., Kooistra H.S., Nelson R., Reusch C.E. \& Scott-Moncrieff J.C. 2013. Diagnosis of spontaneous canine hyperadrenocorticism: 2012 ACVIM consensus statement (small animal). J. Vet. Intern. Med. 27(6):1292-1304. <http://dx.doi.org/10.1111/jvim.12192><PMid:24112317>

Belanger J.M., Bellumori T.P., Bannasch D.L., Famula T.R. \& Oberbauer A.M. 2017. Correlation of neuter status and expression of heritable disorders. Canine Genet. Epidemiol. 4(1):6. <http://dx.doi.org/10.1186/s40575017-0044-6><PMid:28560045>

Benchekroun G., de Fornel-Thibaud P., Rodríguez Piñeiro M.I., Rault D., Besso J., Cohen A., Hernandez J., Stambouli F., Gomes E., Garnier F., Begon D., Maurey-Guenec C. \& Rosenberg D. 2010. Ultrasonography criteria for differentiating ACTH-dependency from ACTH independency in 47 dogs with hyperadrenocorticism and equivocal adrenal asymmetry. J. Vet. Intern. Med. 24(5):1077-1085. <http://dx.doi.org/10.1111/j.1939-1676.2010.0559. $\mathrm{x}><$ PMid:20666982>

Bennaim M., Centola S., Ramsey I. \& Seth M. 2019. Clinical and clinicopathological features in dogs with uncomplicated spontaneous hyperadrenocorticism diagnosed in primary care practice (2013-2014). J. Am. Anim. Hosp. Assoc. 55(4):178-186. <http://dx.doi.org/10.5326/JAAHA-MS-6789> <PMid:31099602>

Bock T. \& Pöppl A.G. 2018. Canine hyperadrenocorticism environmental risk factors: a case-control study. Proceedings 2018 American College of Veterinary Internal Medicine (ACVIM) Forum, Seatlle, WA. 1p.

Caragelasco D.S., Kogika M.M., Martorelli C.R., Kanayama K.K. \& Simões D.M.N. 2017. Urine protein electrophoresis study in dogs with pituitary dependent hyperadrenocorticism during therapy with trilostane. Pesq. Vet. Bras. 37(7):734-740.<http://dx.doi.org/10.1590/s0100-736x2017000700014>

Chervier C., Cadoré J.L., Rodriguez-Piñeiro M.I., Deputte B.L. \& Chabanne L. 2012. Causes of anaemia other than acute blood loss and their clinical significance in dogs. J. Small Anim. Pract. 53(4):223-227. <http://dx.doi. org/10.1111/j.1748-5827.2011.01191.x> <PMid:22417096>

Fracassi F., Malerba E., Furlanello T. \& Caldin M. 2015. Urinary excretion of calcium and phosphate in dogs with pituitary-dependent hypercortisolism: case control study in 499 dogs. Vet. Rec. 177(24):625. <http://dx.doi. org/10.1136/vr.103436><PMid:26626505>

Fracassi F., Corradini S., Floriano D., Boari A., Aste G., Pietra M., Bergamini P.F. \& Dondi F. 2014. Prognostic factors for Survival in dogs with pituitarydependent hypercortisolism treated with trilostane. Vet. Rec. 176(2):49. <http://dx.doi.org/10.1136/vr.102546> <PMid:25170036>

Gallelli M.F., Cabrera M.F.B. \& Castillo V. 2010. A comparative study by age and gender of the pituitary adenoma and ACTH and alpha-MSH secretion in dogs with pituitary-dependent hyperadrenocorticism. Res. Vet. Sci. 88(1):3340. <http://dx.doi.org/10.1016/j.rvsc.2009.06.011> <PMid:19683322>

Gilor C. \& Graves T.K. 2011. Interpretation of laboratory test for canine Cushing's syndrome. Top. Companion Anim. Med. 26(2):98-108. <http:// dx.doi.org/10.1053/j.tcam.2011.03.001><PMid:21596349>

Herrtage M.E. \& Ramsey I.K. 2012. Canine hyperadrenocorticism, p.167189. In: Mooney C.T. \& Peterson M.E. (Eds), BSAVA Manual of Canine and Feline Endocrinology. 4th ed. British Small Animal Veterinary Association, Quedgeley, Gloucester.

Kennedy S.R., Loeb L.A. \& Herr A.J. 2012. Somatic mutations in aging, cancer and neurodegeneration. Mech. Ageing Develop. 133(4):118-126. <http:// dx.doi.org/10.1016/j.mad.2011.10.009><PMid:22079405>

Kim K.H., Han S.M., Jeon K.O., Kim H.T., Li Q., Ryu M.O., Song W.J., Park S.C. \& Youn H.Y. 2017. Clinical relationship between cholestatic disease and pituitary-dependent hyperadrenocorticism in dogs: a retrospective case series. J. Vet. Intern. Med. 31(2):335-342. <http://dx.doi.org/10.1111/ jvim.14608> <PMid:28064467>
Klose T.C., Creevy K.E. \& Brainard B.M. 2011. Evaluation of coagulation status in dogs with naturally occurring canine hyperadrenocorticism. J. Vet. Emerg. Crit. Care 21(6):625-632. <http://dx.doi.org/10.1111/j.1476-4431.2011.00696. $\mathrm{x}><$ PMid:22316255>

Koestel Z.L., Backus R.C., Tsuruta K., Spollen W.G., Johnson S.A., Javurek A.B., Ellersieck M.R., Wiedmeyer C.E., Kannan K., Xue J., Bivens N.J., Givan S.A. \& Rosenfeld C.S. 2017. Bisphenol A (BPA) in the serum of pet dogs following short-term consumption of canned dog food and potential health consequences of exposure to BPA. Sci. Total Environ. 579:1804-1814. <http://dx.doi.org/10.1016/j.scitotenv.2016.11.162><PMid:27932218>

Kooistra H.S. \& Galac S. 2010. Recent advances in the diagnosis of Cushing's syndrome in dogs. Vet. Clin. N. Am., Small Anim. Pract. 40(2):259-267. <http://dx.doi.org/10.1016/j.cvsm.2009.10.002> <PMid:20219487>

Kool M.M.J., Galac S., Spandauw C.G., Kooistra S.H.S. \& Mol J.A. 2013. Activating mutations of GNAS in K9 cortisol-secreting adrenocortical tumors. J. Vet. Intern. Med. 27(6):1486-1492.<http://dx.doi.org/10.1111/jvim.12194> $<$ PMid:24112376>

Kutsunai M., Kanemoto H., Fukushima K., Fujino Y., Ohno K. \& Tsujimoto H. 2014. The association between gall bladder mucoceles and hyperlipidaemia in dogs: a retrospective case control study. Vet. J. 199(1):76-79. <http:// dx.doi.org/10.1016/j.tvjl.2013.10.019><PMid:24268484>

Ling G.V., Stabenfeldt G.H., Comer K.M., Gribble D.H. \& Schechter R.D. 1979. Canine hyperadrenocorticism: pretreatment clinical and laboratory evaluation of 117 cases. J. Am. Vet. Med. Assoc. 174(11):1211-1215. <PMid:438050>

Miceli D.D., Pignataro O.P. \& Castillo V.A. 2017. Concurrent hyperadrenocorticism and diabetes mellitus in dogs. Res. Vet. Sci. 115:425-431. <http://dx.doi. org/10.1016/j.rvsc.2017.07.026><PMid:28759861>

Miceli D.D., Abiuso A.M.B., Vidal P.N., Gallelli M.F., Pignataro O.P. \& Castillo V.A. 2018. Overexpression of $11 \beta$-hydroxysteroid dehydrogenase 1 in visceral adipose tissue and underexpression of endothelial nitric oxide synthase in the adrenal cortex of dogs with hyperadrenocorticism. Open Vet. J. 8(1):77-85.<http://dx.doi.org/10.4314/ovj.v8i1.13><PMid:29721436>

Midzak A. \& Papadopoulos V. 2016. Adrenal mitochondria and steroidogenesis: from individual proteins to functional protein assemblies. Front. Endocrinol. 7:106. <http://dx.doi.org/10.3389/fendo.2016.00106><PMid:27524977>

Mizutani S., Torisu S., Kaneko Y., Yamamoto S., Fujimoto S., Ong B.H.E. \& Naganobu K. 2017. Retrospective analysis of canine gallbladder contents in biliary sludge and gallbladder mucoceles. J. Vet. Med. Sci. 79(2):366-374. <http://dx.doi.org/10.1292/jvms.16-0562><PMid:27990011>

Morgan S.A., McCabe E.L., Gathercole L.L., Hassan-Smith Z.K., Larner D.P., Bujalska I.J., Stewart P.M., Tomlinson J.W. \& Lavery G.G. 2014. 11betaHSD1 is the major regulator of the tissue-specific effects of circulating glucocorticoid excess. Proc. Natl Acad. Sci. USA 111(24):2482-2491. <http:// dx.doi.org/10.1073/pnas.1323681111> <PMid:24889609>

Morgan S.A., Sherlock M., Gathercole L.L., Lavery G.G., Lenaghan C., Bujalska I.J., Laber D., Yu A., Convey G., Mayers R., Hegyi K., Sethi J.K., Stewart P.M., Smith D.M. \& Tomlinson J.W. 2009. 11ß-Hydroxysteroid dehydrogenase type 1 regulates glucocorticoid-induced insulin resistance in skeletal muscle. Diabetes 58(11):2506-2515. <http://dx.doi.org/10.2337/db090525> <PMid:19675138>

Nozawa S., Oda H., Akiyama R., Ueda K., Saeki K., Shono S., Maruyama N., Murata A., Tazaki H., Mori A., Momota Y., Azakami D., Sako T. \& Ishioka K. 2014. Decreased gene expressions of insulin signal molecules in canine hyperadrenocorticism. J. Vet. Med. Sci. 76(8):1177-1182. <http://dx.doi. org/10.1292/jvms.14-0033><PMid:24829079>

O’Neill D.G., Scudder C., Faire J.M., Church D.B., McGreevy P.D., Thomson P.C. \& Brodbelt D.C. 2016. Epidemiology of hyperadrenocorticism among 210.824 dogs attending primary-care veterinary practices in the UK 2009 to 2014. J. Small Anim. Pract. 57(7):365-373.<http://dx.doi.org/10.1111/ jsap.12523><PMid:27279104>

Pace S.L., Creevy K.E., Krimer P.M. \& Brainard B.M. 2013. Assessment of coagulation and potential biochemical markers for hypercoagulability 
in canine hyperadrenocorticism. J. Vet. Intern. Med. 27(5):1113-1120. <http://dx.doi.org/10.1111/jvim.12159> <PMid:23952553>

Pagani E., Tarducci A., Borrelli A., Iotti B., Tursi M. \& Zanatta R. 2017. Accuracy of ultrasonographic measurements of adrenal glands in dogs: comparison with necroscopic findings. Anat. Histol. Embryol. 46(2):187-194. <http:// dx.doi.org/10.1111/ahe.12256><PMid:27753129>

Peterson M.E. 2007. Diagnosis of hyperadrenocorticism in dogs. Vet. Clin. N. Am., Small Anim. Pract. 22(1):2-11. <http://dx.doi.org/10.1053/j. ctsap.2007.02.007><PMid:17542191>

Plassais J., Rimbault M., Williams F.J., Davis B.W., Schoenebeck J.J. \& Ostrander E.A. 2017. Analysis of large versus small dogs reveals three genes on the canine $\mathrm{X}$ chromosome associated with body weight, muscling and back fat thickness. PLoS Genet. 13(3):1006661. <http://dx.doi.org/10.1371/ journal.pgen.1006661 ><PMid:28257443>

Pöppl A.G., Coelho I.C., Silveira C.A., Moresco M.B. \& Carvalho G.L.C. 2016. Frequency of endocrinopathies and characteristics of affected dogs and cats in southern Brazil (2004-2014). Acta Scient. Vet. 44:1379.

Ramsey I. \& Ristic J. 2007. Diagnosis of canine hyperadrenocorticism. In Practice 29(8):446-454. <http://dx.doi.org/10.1136/inpract.29.8.446>

Reusch C.E. \& Feldman E.C. 1991. Canine hyperadrenocorticism due to adrenocortical neoplasia: pretreatment evaluation of 41 dogs. J. Vet. Intern. Med. 5(1):3-10. <http://dx.doi.org/10.1111/j.1939-1676.1991.tb00922. $\mathrm{x}><$ PMid:1850483>

Rose L., Dunn M.E. \& Bédard C. 2013. Effect of canine hyperadrenocorticism on coagulation parameters. J. Vet. Intern. Med. 27(1):207-211. <http:// dx.doi.org/10.1111/jvim.12005><PMid:23278831>

Smets P.M.Y., Lefebvre H.P., Aresu L., Croubels S., Haers H., Piron K., Meyer E. \& Daminet S. 2012a. Renal function and morphology in aged beagle dogs before and after hydrocortisone administration. PLoS One 7(2):e31702. <http://dx.doi.org/10.1371/journal.pone.0031702><PMid:22393368>

Smets P.M.Y., Lefebvre H.P., Meij B.P., Croubels S., Meyer E., Maele I. \& Daminet S. 2012b. Long-term follow-up of renal function in dogs after treatment for ACTH dependent hyperadrenocorticism. J. Vet. Intern. Med. 26(3):565-574. <http://dx.doi.org/10.1111/j.1939-1676.2012.00915.x><PMid:22463105>

Soares F.A.C., Matheus J.P., Carvalho G.L., Neuwald E.B., Pöppl A.G., Valle S.F. \& González F.D.H. 2016. Cardiocirculatory, biochemical and hemostatic evaluation of dogs with hyperadrenocorticism at diagnosis and after treatment. Korean J. Vet. Res. 56(3):161-166. <http://dx.doi.org/10.14405/ kjvr.2016.56.3.161>
Sonnenschtein C. \& Soto A. 2010. Environmental causes of cancer: endocrine disruptors as carcinogens. Nature Rev. Endocrin. 6(7):363-370. <http:// dx.doi.org/10.1038/nrendo.2010.87> <PMid:20498677>

Soulsby S.N., Holland M., Hudson J.A. \& Behrend E.M. 2015. Ultrasonography evaluation of adrenal gland size compared to body weight in normal dogs. Vet. Radiol. Ultrasound 56(3):317-326. <http://dx.doi.org/10.1111/ vru.12236><PMid:25496665>

Teshima T., Hara Y., Takekoshi S., Teramoto A., Osamura R.Y. \& Tagawa M. 2009. Expression of genes related to corticotropin production and glucocorticoid feedback in corticotroph adenomas of dogs with Cushing's disease. Domest. Anim. Endocrinol. 36(1):3-12. <http://dx.doi.org/10.1016/j. domaniend.2008.08.002><PMid:18818046>

Theon A.P. \& Feldman E.C. 1998. Megavoltage irradiation of pituitary macrotumors in dogs with neurologic signs. J. Am. Vet. Med. Assoc. 213(2):225-231. <PMid:9676592>

van Wijk P.A., Rijnberk A., Croughs R.J., Meij B.P., van Leeuwen I.S., Sprang E.P. \& Mol J.A. 2014. Molecular screening for somatic mutations in corticotropic adenomas of dogs with pituitary-dependent hyperadrenocorticism. J. Endocrinol. Invest. 20(1):1-7.<http://dx.doi.org/10.1007/BF03347964> <PMid:9075064>

Vidal P.N., Miceli D.D., Arias E.S., D’Anna E., García J.D. \& Castillo V.A. 2018. Decrease of nitric oxide and increase in diastolic blood pressure are two events that affect renal function in dogs with pituitary dependent hyperadrenocorticism. Open Vet. J. 8(1):86-95. <http://dx.doi.org/10.4314/ ovj.v8i1.14><PMid:29721437>

Wang Y., Brûlé E., Silander T., Bak B., Joustra S.D. \& Bernard D.J. 2017. The short mRNA isoform of the immunoglobulin superfamily, member 1 gene encodes an intracellular glycoprotein. Plos One 12(7):e0180731.<http:// dx.doi.org/10.1371/journal.pone.0180731><PMid:28686733>

Wooten K.J. \& Smith P.N. 2013. Canine toys and training devices as sources of exposure to phthalates and bisphenol A: quantitation of chemicals in leachate and in vitro screening for endocrine activity. Chemosphere 93(10):2245-2253.<http://dx.doi.org/10.1016/j.chemosphere.2013.07.075> $<$ PMid:24007620>

Zhang Y., Dong S., Wang H., Tao S. \& Kiyama R. 2016. Biological impact of environmental aromatic hydrocarbons (ePAHs) as endocrine disruptors. Environ. Pollut. 213:809-824. <http://dx.doi.org/10.1016/j. envpol.2016.03.050><PMid:27038213> 